\title{
Prospects of application of roller compacted concrete in hydro schemes of Ukraine
}

\author{
Svitlana Butnik ${ }^{1, *}$, and Andrii Mozgovyi ${ }^{2}$ \\ ${ }^{1}$ Kharkiv National University of Civil Engineering and Architecture, Department of Building Technology, 40 Sumska Str., Kharkiv, \\ 61002, Ukraine \\ ${ }^{2}$ Kharkiv National University of Civil Engineering and Architecture, Department of Geotechnics, Underground and Hydrotechnical \\ Structures, 40 Sumska Str., Kharkiv, 61002, Ukraine
}

\begin{abstract}
Prospects of application of roller compacted concrete in hydro schemes of Ukraine are considered. The number of dams erected with application of roller compacted concrete is growing year after year in the world. Roller compacted concrete is an especially dry concrete mixture with decreased content of cement and increased content of pozzolana (fly ash). The broad physico-mechanical peculiarities of roller compacted concrete depend not only on its composition but also on technology of its laying and compacting in dam. Rapid construction of gravity dams with use of equipment for earth-moving works enables the more economic construction of protective embankments. Prospects of application of roller compacted concrete during erection and restoration of existing protective embankments in regions with increased flood hazard in the west of Ukraine are considered. The use of roller compacted concrete allows reducing construction deadlines by a factor of $2-3$, and, in so doing, reducing the labor content by a factor of 4-5 at the expense of full mechanization of works. Decrease in content of binder in composition of roller compacted concrete by 30 $80 \mathrm{~kg} / \mathrm{m}^{3}$ favors decrease in heat release and, correspondingly, the occurrence of temperature contraction cracks, which in its turn favors economy during construction of hydro-technical structures of hydro schemes.
\end{abstract}

\section{Critical review of the present state of art of application of roller compacted concrete in hydro-technical construction}

Application of roller compacted concrete is the most important achievement in technology of erection of concrete dams over the last forty years. The use of roller compacted concrete allows reducing deadlines of construction of dams by a factor of 2-3 and, in so doing, reducing the labor content by a factor of $4-5$ at the expense of full mechanization of works [1]. Besides, application of roller compacted concrete gives designers the possibility of economical restoration of existing concrete dams that do not have sufficient resistance against shear and require installation of counterforts, and also the possibility of reconstruction of dams made of soil materials.

Rapid worldwide acceptance of roller compacted concrete is a result of its economically successful application in combination with high technological properties. The idea of combination of advantages of laying of loose materials and concrete as a construction material for dams was developed in 1960s. Materials that can be considered as roller compacted concrete were used during 1960s-1970s [2-3].

The idea of roller compacted concrete arose not by chance, and already in 1961-1964 years in Italy in construction of gravity dam Alpe Gera (height $174 \mathrm{~m}$, volume of concrete 1.7 million $\mathrm{m}^{3}$ ), and also in 1969$1979 \mathrm{yr}$. in USSR in construction of Toktogul'skaya dam (height $215 \mathrm{~m}$, concrete volume 3.2 million $\mathrm{m}^{3}$ ), for the first time the technology of single-layer concreting (layers thickness $0.5-1 \mathrm{~m}$ ) of big blocks with area up to 2.5 thousand $\mathrm{m}^{2}$ was successfully used [4]. At the abovementioned hydro schemes for the first time dry lean concrete with cement consumption of $115-150 \mathrm{~kg} / \mathrm{m}^{3}$ was used, which levelling was performed by small-sized bulldozers, and compaction - by suspended packs of vibrators.

Rapid construction of gravity dams with the use of equipment for earth-moving works including big rollers for compaction was proposed in 1965 as a viable approach to the more economical building of dams [5]. Nevertheless, it had not attracted big attention till in 1970 J.M. Raphael presented it as "optimum gravity dam" [6]. Later, a number of ideas based on the theory of soil cement were presented, and also the conception of laying and compaction of embankment with material enriched with cement with the help of complex equipment for compaction was proposed. In time, this resulted in considerable decrease in cross-section of dams made of roller compacted concrete compared with traditional rockfill dams [3]. Later, the ideas of J.M. Raphael were realized by other engineers in application of enriched

\footnotetext{
* Corresponding author: butniksvet@gmail.com
} 
mixtures instead of lean ones in upstream and downstream faces of dams [3].

In 1970 s a number of organizations carried out a complex of laboratory tests to study properties of monolithic roller compacted concrete. In time, designing dams made of roller compacted concrete was developing in three different directions. Those were alternatives developed by Corps of Engineers of USA, British engineers, and the group of researchers from Japan. Corps of Engineers of USA developed the alternative of lean concrete on the basis of the technology of processing of soil. The British engineers concentrated on the method with high content of paste, and the group of Japanese researchers created a new conception known as RCD (dam of rolled concrete) [3].

The goal of the investigation is a critical review of tendencies of application of roller compacted concrete, existing in the world, in hydrotechnical construction, determination of main advantages and disadvantages of this technology. The tasks of the investigation are determination of the area of application of roller compacted concrete to erect new and restore existing hydrotechnical structures to satisfy vital needs in Ukraine.

\section{Technological aspects of application of roller compacted concrete in hydro- technical structures}

According to ACI 207.5R-89 terminology the roller compacted concrete is defined as "concrete compacted by roller rolling". Concrete mixture in unhardened state permits motion of construction machines over its surface [7]. Bulletin 126 ICOLD determines the roller compacted concrete as "concrete with non-shrinking consistency in its unhardened state, which is transported, laid, and compacted with the use of equipment for construction of earth-fill dams" [8]. Dynamics of increase of the number of dams of roller compacted concrete in the world by data [9-10] is presented in Fig. 1.

Technological peculiarities of roller compacted concrete are determined by the fact that it is concrete with zero shrinkage, which properties strongly depend on proportions of the mixture and on quality of compaction. Roller compacted concretes are produced from especially dry concrete mixtures that defy compaction by internal vibrators. Their compaction is performed by rolling by vibration rollers, heavy motor cars, pneumatic-tired rollers, and other mechanisms during laying mixtures $0.25-0.75 \mathrm{~m}$ [11].

The prepared mixture of roller compacted concrete must be so dry that heavy cars could move over it, and, in so doing, must contain enough water and binder to be amenable to compaction during rolling by mechanisms selected for this purpose.

Because lesser amount of water is used, lesser cement is necessary to prepare equivalent water-to-cement ratio. Lesser amount of water in the mixture causes decrease in shrinkage during solidification, and lesser amount of cement gives lesser heat generation. Decrease in shrinkage during solidification and in heat generation jointly decrease occurrence of temperature contraction cracks. Besides, decreased content of water and rolling by vibration rollers increase specific gravity of roller compacted concrete.

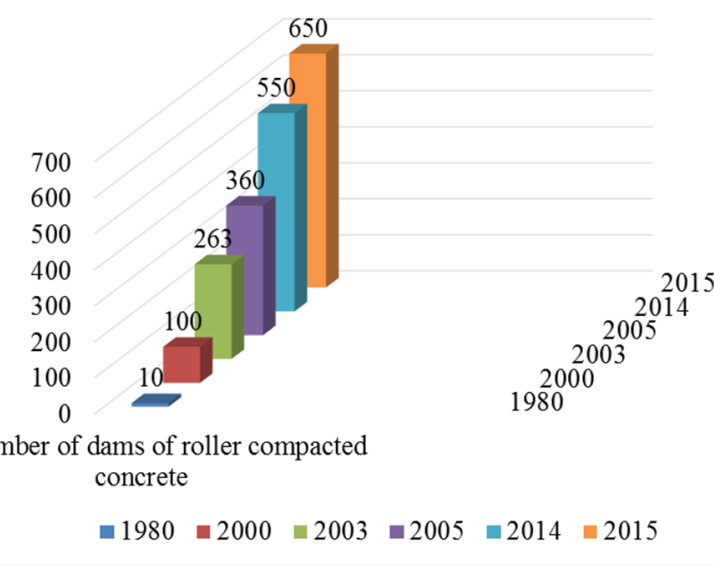

Fig. 1. Dynamics of increase of the number of dams of roller compacted concrete in the world.

Some mixtures of roller compacted concrete can have properties and characteristics similar to conventional concrete, but, for the most part, roller compacted concrete has unique properties that can substantially differ from properties and characteristics of conventional concrete. Roller compacted concrete, as a rule, is transported by trucks or by another way and is kept in heaps or spoil banks in the area of laying. During laying, roller compacted concrete is spread with layers with help of bulldozers and is compacted with help of vibration rollers.

Peculiarities that distinguish roller compacted concrete from conventional concrete are:

- binder content lesser by $30-80 \mathrm{~kg} / \mathrm{m}^{3}$;

- high initial strength, which ensures the possibility of motion of heavy cars and mechanisms over it (with unit pressure up to $1.0 \mathrm{MPa}$ ) immediately after laying and compaction;

- low shrinkage $(1-5) \times 10^{-4}$;

- low heat release, adiabatic increase of temperature for concrete with astringent content $100-130 \mathrm{~kg} / \mathrm{m}^{3}$ does not exceed $12-14^{\circ} \mathrm{C}$;

- density is decreased by $1-5 \%$;

- higher filtration coefficient $1 \times 10^{-4}-1 \times 10^{-8} \mathrm{~cm} / 24 \mathrm{~h}$;

- deformation modulus is lesser by $10-20 \%$;

- increased nonuniformity: for grain size of aggregate up to $40 \mathrm{~mm}$ coefficient of variation of strength value $\mathrm{C}_{\mathrm{v}}$ is $0.20-0.22$, for aggregate grain size $100-200 \mathrm{~mm}-$ respectively $0.27-0.3$.

Continuous increase of intensity of laying of roller compacted concrete is observed. Average intensity of laying at large dams reaches $10-14$ thousand $\mathrm{m}^{3} / 24 \mathrm{~h}$ and 220 thousand $\mathrm{m}^{3} /$ month, which corresponds to intensity of filling of earth dams. Additional increase of intensity is possible at the expense of acceleration of delivery of mixture to a dam.

In world practice there is experience of application of roller compacted concrete not only to build high dams but also to restore small dams of earth materials with insufficient spillway power [12]. 
On this basis, roller compacted concrete in hydrotechnical construction can be actively used in two directions - in new construction and to restore dangerous dams of earth materials.

\section{Prospects of application of roller compacted concrete in hydro schemes of Ukraine}

The authors of the paper ask themselves a question about prospect and expediency of application of roller compacted concrete in conditions of Ukraine. Proceeding from the real assessment of economic state of our country we consider that application of roller compacted concrete is the most expedient for new construction and also for repairs and reconstruction of existing hydro technical structures.

The performed analysis of existing hydro technical structures of Ukraine has proved that the most prospective direction is application of roller compacted concrete to restore the existing small hydroelectric power plants and to construct new dykes at territories that suffer from floods. Ukraine has significant potential in the field of small hydropower - more than 60 thousand small rivers in the country. This resource can be used to supply energy to both regional centers, and remote areas and villages. Experts from the United Nations and the International Center for Small Hydropower believe that more than 100 neglected Ukrainian small hydropower plants can be reconstructed, and several hundreds of small hydropower projects can be implemented. The relevance of such decisions is reflected in the "Energy Strategy of Ukraine for the period until 2030" and in the updated "Energy Strategy of Ukraine for the period until 2035" [13].

The Carpathian Mountains area is the most promising in terms of reconstruction of former small hydropower plants and construction of new ones. If we consider the most vulnerable elements of the existing dams of small hydropower plants, we should pay special attention to the dam spillways. Due to the use of roller compacted concrete, it is possible to solve a number of such problems as the arrangement of the overflow over the dam crest, the arrangement of the cascade spillway, which extinguishes the energy of the water flow effectively, and strengthening of the existing berm etc. This experience is thoroughly covered in [12].

The urgent issue for Ukraine is the construction of protective and enclosing structures to protect the areas from flooding. First of all, areas in western Ukraine are concerned. According to [14], the floods of 1995, 1998, 2008, 2010 and 2017 in this region caused losses of more than eight billion hryvnias. Large losses to this region were caused by the flood in the summer of 2020 .

In Ukraine realization of several state target programs of complex flood protection in the basins of rivers Tisza, Dniester, Prut, and Siret is performed. To date, a complex of protective flood structures that includes 3.5 thousand $\mathrm{km}$ of embankments, 1.2 thousand $\mathrm{km}$ of coast-protecting structures, more than 600 pumping and compressor plants to pump over surpluses of water is already created. But the complex of protective structures at rivers and reservoirs is insufficient and requires substantial reconstruction of the operating and construction of new ones [15-17].

According to data [18] the protective flood structures are made from local materials, which substantially reduces the cost of construction (see Fig. 2).

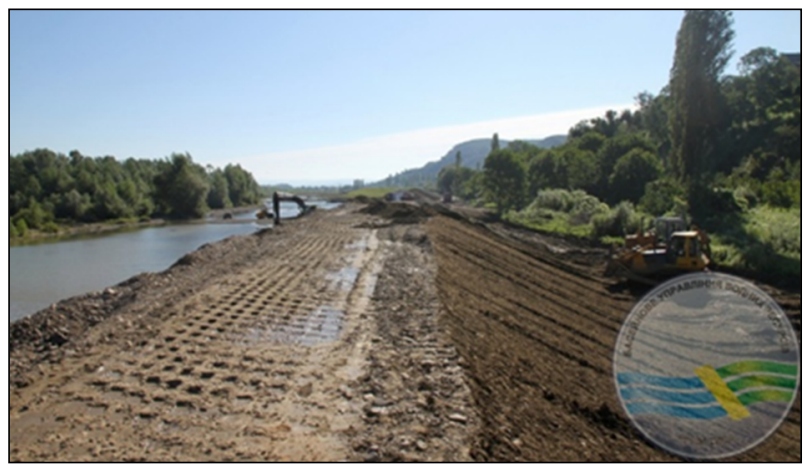

Fig. 2. Arrangement of the downstream slope of an earth-filled protective embankment dam [18].

But in earth embankments during each moistening for many years, the smallest particles of ground are washed away, i.e. mechanical suffosion takes place, which leads to natural ageing of the dam and decrease of its reliability [19]. The most typical example of the destruction of the waterside slope protection is presented in Fig. 3. You can clearly see the fact of mechanical erosive leakage, exposure of the reinforcement and its surface corrosion.

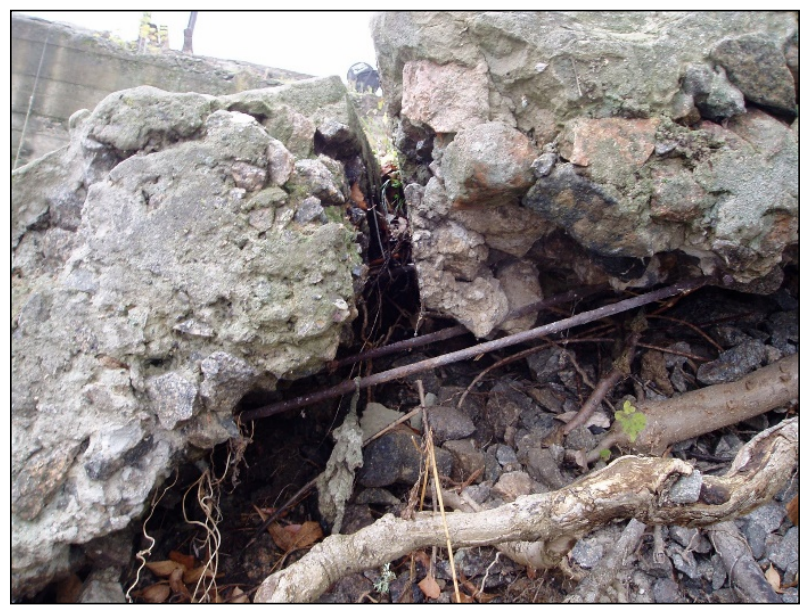

Fig. 3. Damaged area of the waterside protection.

Among the 215 existing dams, 16 are in unsatisfactory condition and, correspondingly, require repair (see Fig. 4)

Fig. 5 presents the number of dams classified proceeding from the annual probability of exceeding (provision) the estimated maximum of water consumption.

The main number of dams that are in poor condition and need repairment were built in the $60 \mathrm{~s}$ and $70 \mathrm{~s}$ of the last centuries. Accordingly, they are in operation during 57 to 44 years.

Analysis of the number of dams in unsatisfactory condition is shown in Fig. 6. 


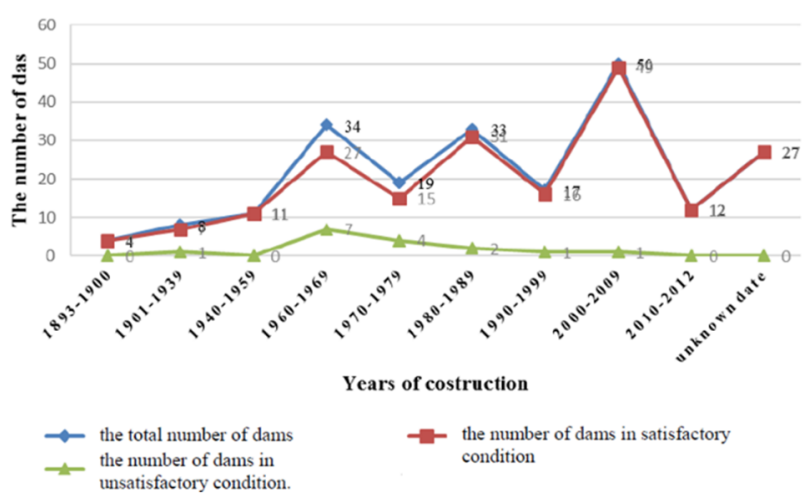

Fig. 4. Number and condition of protective dams in western Ukraine.

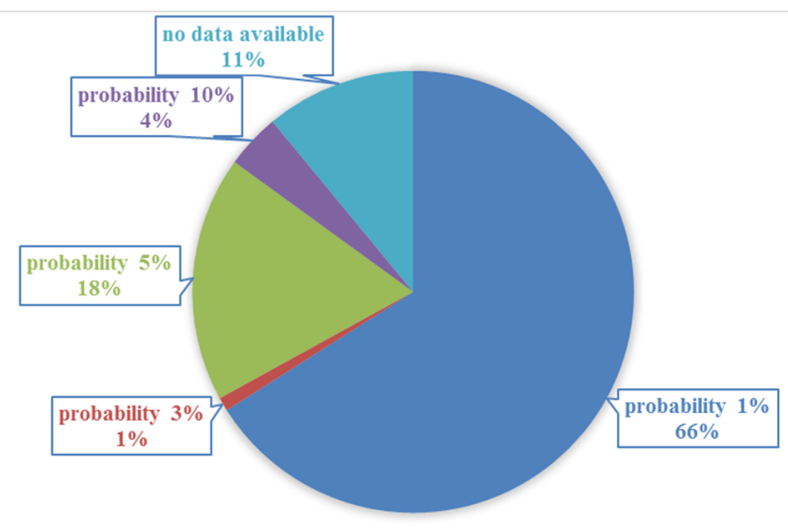

Fig. 5. The number of dams that are classified proceeding from the annual probability of exceeding the estimated maximum of water consumption.

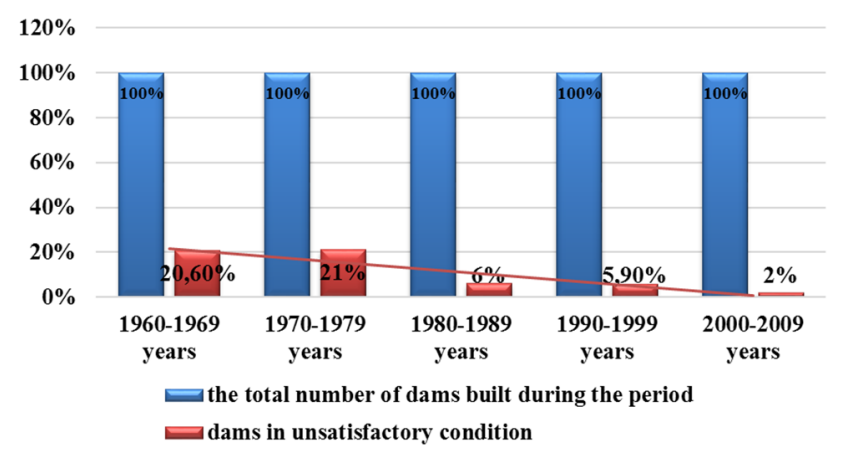

Fig. 6. Number of dams that are in unsatisfactory condition.

On average, $20 \%$ of dams that have been operating for more than 50 years are in unsatisfactory condition (see Fig. 6). And accordingly, the shorter the operating time, the lower the percentage of dams in poor condition is.

All these structures belong to the $\mathrm{CC} 2$ and the $\mathrm{CC} 1$ consequences classes [20]. Respectively, $66 \%$ of these dikes/dams belong to the CC2-1 consequences class, $1 \%$ to $\mathrm{CC} 2-2$ and $18 \%$ to $\mathrm{CC} 1$.

Assigned service life for buildings that belong to the $\mathrm{CC} 2-2$ and the $\mathrm{CC} 1$ consequences classes makes 50 years, and for CC2-1 - 100 years [20]. This means that almost half of the existing dikes are approaching their design life or their design life has already expired. Therefore, there is the need for implementation of modern technologies for the restoration or new construction of this type of protective structures.
Significant funds are allocated for repairs every year. But the main constructive decision on reconstruction and restoration of protective and enclosing dams is dumping of rock filling (Fig. 7) sometimes using tinning.

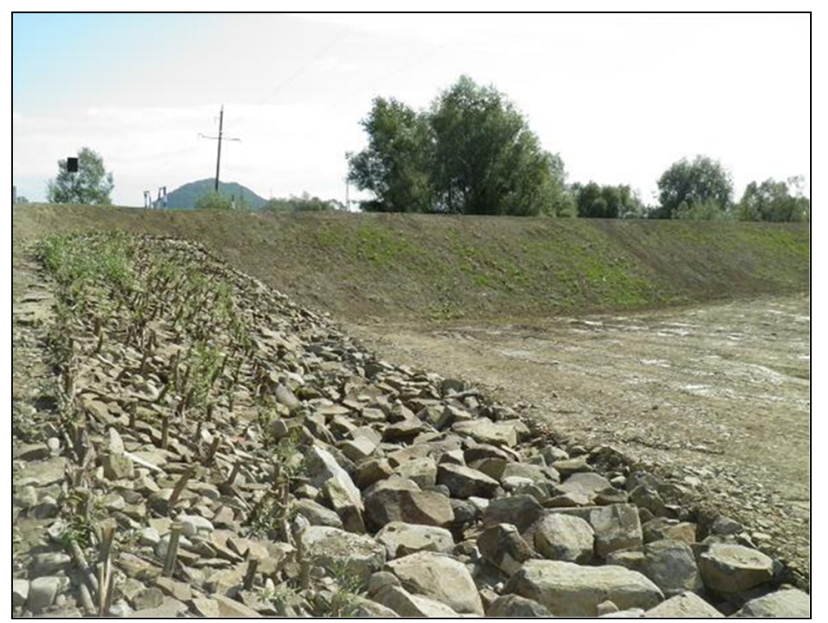

Fig. 7. Reconstructed protective dam to protect the city of Khust from floods (2011) [21].

The fair question arises, why a lot of money should be spent every year on repair and restoration work to face the same problem next year. Maybe it is better to make a reliable building that is resistant to destruction for many years and solve the problem of flooding in this region.

It is the technologies of roller compacted concrete that can solve the problems of construction of new protective dikes and give the possibility to perform high quality reconstruction of already existing ones.

When considering such indicator like the cost of construction, it is necessary to pay attention to accidentfree operation of hydro technical protective structures for a long time. Protective structures made from roller compacted concrete are less amenable to eroding action of water stream and permit overflow over the crest unlike dams made of earth materials.

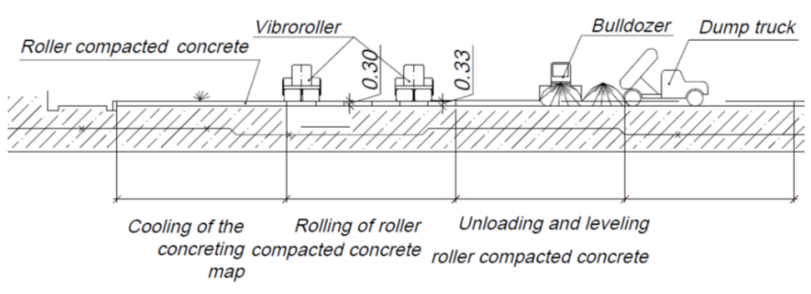

Fig. 8. Technology of roller compacted concrete placing.

Technology of erection of dams from roller compacted concrete should be considered as a part of the uninterrupted construction process with high degree of mechanization of transportation of concrete to the place of laying, its distribution by maps, and compaction. The minimum width of the area of concreting should be considered equal to two vehicle widths (see Fig. 8).

When performing work, it is recommended to have three sites at the same time:

- on the first site the rolling of the placed concrete mix should be performed; 
- on the second site the unloading and spreading of the concrete mix should be performed;

- on the third site the preparation of the base for the concrete mix placing should be performed.

The dimensions of the concreting maps should be related to the performance of the mechanisms, concrete pouring intensity and thickness of the RCC layer.

The width of the maps is taken to be at least twice the width of the compacting mechanism, and the length coincides with one of the dimensions of the concreting unit. When compacting the adjacent map, the compacting mechanism must overlap the previous one by at least $0.2-$ $0.5 \mathrm{~m}$.

With limited supply intensity of the concrete mix, the minimum length of the grips should be such that the mix would be placed in a reasonable time and ensuring the effective operation of the compacting mechanism at the same time.

Regardless of the method of supplying of the hardconcrete mix on the concreting map - the height of the pile should not exceed $0.65 \mathrm{~m}$.

When placing RCC, its screeding is done by bulldozers using flat dumps.

The layer should have a slight slope towards the downstream area.

The use of towed vibratory rollers is allowed, if the configuration of the structures allows.

Placing of the concrete mix should be conducted in layers of $33 \mathrm{~cm}$, the calculated thickness of a layer in the compacted condition should be accepted equal to $30 \mathrm{~cm}$ (Fig. 8). The deviation of the thickness of the mix layer after screeding is $\pm 5 \mathrm{~cm}$.

Rolling of the concrete mix requires 4-6 passes of a vibrating roller. The number of passes is specified during the research work.

The first and the last two passes must be made with the vibration exciter off.

One of the main factors that facilitates economic and high-quality construction of dams of roller compacted concrete is their relatively simple construction that requires minimal interference into the process of concrete placement and allows a contractor to perform construction without interruptions and quickly. Due to technology of roller compacted concrete it is not construction that influence technology but technology determines construction of structure. Flood protective dams have simple construction and the technology of roller compacted concrete is the most expedient for their erection.

Quick placement of roller compacted concrete has advantages also in reconstruction of dams that can have only limited time till completion of construction works before re-introduction of structure into operation.

New construction is performed by the traditional technology of roller compacted concrete. Delivery of concrete to a place of laying should be performed in dump trucks.

\section{Analysis of composition of binding substances of roller compacted concrete}

To prepare rolled concrete, it is necessary to use local materials, crushed stone, sand. Composition of roller compacted concrete is selected by experiment.

Replacement of a part of cement in a composition of roller compacted concrete by fly ash or by natural pozzolana will allow decreasing heat release, and correspondingly will decrease formation of cracks, increases longevity, and allows decreasing a cost of dam construction.

The world experience allows contending that it is due to inclusion of fly ash or pozzolana that this experience can be used in conditions of Ukraine [4]. The data are presented in Table 1.

Table 1. Statistical data on content of binder in roller compacted concrete of dams.

\begin{tabular}{|c|c|c|c|c|}
\hline $\begin{array}{c}\text { Co- } \\
\text { untry }\end{array}$ & $\begin{array}{c}\text { Num- } \\
\text { ber of } \\
\text { dams/ } \\
\text { dikess }\end{array}$ & $\begin{array}{c}\text { Cement } \\
\text { consumpti- } \\
\text { on, } \mathbf{k g} / \mathbf{m}^{3}: \\
\text { average/ } \\
\text { maximal }\end{array}$ & $\begin{array}{c}\text { Pozzolana } \\
\text { consumption, } \\
\text { kg/m } \mathbf{m}^{\mathbf{3}} \text { avera- } \\
\text { ge/ maximal }\end{array}$ & $\begin{array}{c}\text { Total binder } \\
\text { consumption, } \\
\mathbf{k g} / \mathbf{m}^{3}: \text { ave- } \\
\text { rage/ maximal }\end{array}$ \\
\hline China & 62 & $79 / 140$ & $94 / 140$ & $173 / 230$ \\
\hline Brazil & 52 & $70 / 80$ & $15 / 50$ & $85 / 100$ \\
\hline Japan & 41 & $87 / 96$ & $35 / 78$ & $122 / 130$ \\
\hline USA & 37 & $85 / 184$ & $53 / 173$ & $138 / 252$ \\
\hline Spain & 22 & $75 / 88$ & $133 / 170$ & $208 / 270$ \\
\hline
\end{tabular}

\section{Analysis of results}

The technology of layer wise erection of dams with the use of rolled concrete is the most effective for construction of concrete dams. It allows decreasing deadlines of construction of hydro schemes by a factor of 2-3 and to reduce the laboriousness by a factor of 4-5 due to full mechanization of concrete works with the use of present-day highly productive equipment, and also due to simplification and more rational organization of construction. Technology of rolled concrete allows creating firm reliable and safe dams (a number of such dams endured several strong earthquakes and did not get any damage).

Dams of roller compacted concrete can be erected in different natural and climatic conditions (hot climate, low temperatures, considerable amount of precipitation).

Regulated technological systems used in erecting dams by single-layer blocks are defined by increased reliability and durability, which allows planning concrete works accurately, and, in so doing, design and actual schedules of concreting as a rule concur. This allows using all highly productive equipment for concrete placement fully. 


\section{Conclusion}

The presented investigations can be used for new construction and reconstruction of existing small hydro power plants and protective dams in regions with increased flood hazard primarily in the west of Ukraine.

In our country there is an urgent problem and potential opportunities for construction and restoration of a significant number of hydraulic structures. Thanks to modern and highly productive technology of roller compacted concrete it can be carried out in the minimum terms and with the maximum productivity.

\section{References}

[1] V.B. Sudakov, Construction of dams from rolled concrete. Prospects and challenges (OAO VNIIG im. B E Vedeneeva, Leningrad, 2011), p. 42

[2] Concrete Gravity Dam Built Like Earthfill, ENR 173 (1964)

[3] G. Gentile, Study, preparation, and placement of Low Cement Concrete, with special regard to its use in Solid Gravity Dams Transactions. Paper presented at the International Congress on Large Dams and International Commission on Large Dams (ICOLD), R16 Q30, France, Paris, 1964

[4] Yu.P. Lyapichev, Proektirovanie $i$ stroitelstvo sovremennyh vysokih plotin (Izd-vo RUDN, Moskva, 2004), p. 275

[5] T.D. Humphreys, F.M. Jardine, J.K. Nash, The economic and physical feasibility of Soil-Cement Dams. Paper presented at the 6th International conference on soil mechanics and foundation engineering, vol II, Canada, 1965

[6] J.M. Raphael, The optimum gravity dam. Rapid construction of concrete dams. ASCE 221-247 (1971)

[7] Roller-Compacted Mass Concrete. ACI Committee 207.5R-89 1988 (American Concrete Institute, 1988), p. 47

[8] Roller Compacted Concrete Dams. ICOLD Bulletin 126 (International Commission on Large Dams (ICOLD), France, Paris, 2003), p. 480

[9] RCC Dams: Simplicity is the key to success (Water Power \& Dam Construction), https://www.waterpowermagazine.com/features/feat urercc-dams-simplicity-is-the-key-to-success4219225/. Accessed 20 June 2020

[10] The World's Largest Roller-Compacted Concrete Dams (ENR), https://www.enr.com/articles/5971the-world-s-largest-roller-compacted-concretedams. Accessed 20 June 2020

[11] Recommendations on the use of rolled concrete in hydraulic engineering (Leningrad, VNIIG, 1985), p. 21

[12]P. Timothy, Dolen, Y.A. Fares, Roller compacted concrete for dam safety modifications. Paper presented at the Brazilian International RCC Symposium, Brazil, IBRACON, 2008

[13] Enerhetychna stratehiia Ukrainy na period do 2035 roku,

http://mpe.kmu.gov.ua/minugol/control/uk/publish/a rticle?art_id=245239564\&cat_id=245239555.

Accessed 20 June 2020

[14] Pavodkamy ta poveniamy mozhna upravliaty Nadzvychaina sytuatsiia, https://nsplus.com.ua/2017/04/24/pavodkamy-ta-povenyamymozhna-upravlyat/. Accessed 20 June 2020

[15] Postanova Kabinetu Ministriv Ukrainy vid 3 lypnia 2006 r № 901 Pro zatverdzhennia Kompleksnoi prohramy zakhystu silskykh naselenykh punktiv i silskohospodarskykh uhid vid shkidlyvoi dii vod na period do 2010 roku ta prohnoz do 2020 roku Ofitsiinyi visnyk Ukrainy, 2006 r № 27, st 1942, http://zakon2.rada.gov.ua/laws/show/901-2006-п. Accessed 20 June 2020

[16]Zakhyst vid nebezpechnykh heolohichnykh protsesiv, shkidlyvykh ekspluatatsiinykh vplyviv, vid pozhezhi. Inzhenernyi zakhyst terytorii ta sporud vid pidtoplennia ta zatoplennia. DBN V.1.1-25-2009 (Minrehionbud Ukrainy, Kyiv, 2009), p. 52

[17] Informatsiino-analitychna dovidka shchodo problem kompleksnoho protypavodkovoho zakhystu terytorii rehioniv Ukrainy vid katastrofichnykh pavodkiv ta minimizatsii zbytkiv vid shkidlyvoi dii vod. Protypavodkovyi zakhyst Derzhavne ahentstvo vodnykh resursiv Ukrainy, https://scwm.gov.ua/. Accessed 12 May 2020

[18] Vodohospodarska sytuatsiia Baseinove upravlinnia vodnykh resursiv richky Tysa, http://buvrtysa.gov.ua/newsite/?page_id=105. Accessed 10 May 2020

[19]A.A. Biletskyi, S.V. Klimov, Tendentsii rozvytku inzhenernykh zakhodiv zakhystu terytorii ta naselenykh punktiv vid zatoplennia. Problemy vodopostachannia, vodovidvedennia ta hidravliky. 28, 30-36 (2017), http://nbuv.gov.ua/UJRN/PVVG_2017_28_6. Accessed 20 June 2020

[20]Hidrotekhnichni sporudy. Osnovni polozhennia. DBN V.2.4-3:2010 (DP Ukrarkhbudinform, Kyiv, 2010), p. 37

[21]U zakarpatskomu Khusti urochysto vidkryly protyvopavodkovi damby, https://zakarpattya.net.ua/News/87855-Uzakarpatskomu-KHusti-urochysto-vidkrylyprotyvopavodkovi-damby. Accessed 10 May 2020 